\title{
Simulation Analysis for Bitumen Residuum Concrete Core Wall Rockfill Dam of White River Hydropower Station
}

\author{
Dongyu $\mathrm{Ji}^{\mathrm{a}}$ \\ Hunan Urban Construction College, Xiangtan, Hunan Province 411101, P.R. China \\ ahnjdy@126.com
}

Keywords: Bitumen residuum concrete, Rockfill dam, Finite element, Simulation analysis

\begin{abstract}
Through analyzing bitumen residuum concrete core wall rockfill dam structure's mechanical characteristics in construction process and operational process, this paper adopts finite element method to carry out simulation analysis for bitumen residuum concrete core wall rockfill dam of White River hydropower station. Deducing distribution law of the dam's stress and displacement in construction process and operational process. Analysis results show that, bitumen residuum concrete core wall rockfill dam of White River hydropower station construction is reasonable, it meets the requirements for design.
\end{abstract}

\section{Introduction}

White River hydropower station is located the Sandao White River, which is located Antu county in Jilin province. Rainwater-collecting area is $1379 \mathrm{~km}^{2}$. Total reservoir storage capacity is 356 million $\mathrm{m}^{3}$, function of the engineering is generate electricity, installed capacity is $6000 \mathrm{~kW}$. The engineering is make by the dam, spillway, spillway tunnel and water diversion system, etc. The dam is bitumen residuum concrete core wall rockfill dam, right bank beach links with clay core wall dam, spillway and water inlet of hydropower station's diversion canal are located left bank. Maximum dam high is $23.3 \mathrm{~m}$, dam crest width is $4.5 \mathrm{~m}$, gradient of upstream face is 1:1.5, gradient of downstream face is 1:1.5. Reservoir's normal storage level is $18.8 \mathrm{~m}$, design level is $19.6 \mathrm{~m}$, flood level is $21.7 \mathrm{~m}$.

\section{Calculation Model}

Model Parameters. Concrete strength grade of White River hydropower station's bitumen residuum concrete core wall rockfill dam is $\mathrm{C} 15$, elastic modulus $\mathrm{E}_{1}=22 \mathrm{GPa}^{[1]}$, Poisson ratio $\mu_{1}=0.167$, density $\gamma_{1}=24 \mathrm{kN} / \mathrm{m}^{3}$. The dam masonry's elastic modulus $\mathrm{E}_{2}=20 \mathrm{GPa}$, Poisson ratio $\mu_{2}=0.28$, density $\gamma_{2}=30 \mathrm{kN} / \mathrm{m}^{3}$. The dam foundation rock is basalt, rock elastic modulus $\mathrm{E}_{3}=17$ $\mathrm{GPa}^{[2]}$, Poisson ratio $\mu_{3}=0.21$.

Element Division. Finite element simulative analysis is proceeded for bitumen residuum concrete core wall rockfill dam of White River hydropower station. bitumen residuum concrete core wall, rockfill dam and bedrock structure model is divided by eight nodes isoparametric block element. The element is often applied to three-dimensional model of entity structure, it has plasticity, creep, expansion, stress rigidization, large deformation and large strain characteristics. it has eight nodes, each node has three translational degree of freedoms ${ }^{[3]}$.

Simulation Range. Universal finite element calculation software is adopted, finite element simulative analysis for bitumen residuum concrete core wall rockfill dam of White River hydropower station. Calculation model simulation range is listed below, calculation model along the river is $194.5 \mathrm{~m}$, transverse of the river is $70 \mathrm{~m}$, vertical direction is $103.3 \mathrm{~m}$. The simulation range of whole calculation model is $194.5 \mathrm{~m} \times 70 \mathrm{~m} \times 103.3 \mathrm{~m}{ }^{[4]}$. Element division of dam and bedrock is shown in Fig.1.

Calculation Cases. Considering mechanical characteristics of dam structure in construction and operating process ${ }^{[5]}$, researching four calculation cases as follows. Case 1 , dam weight(construction condition); case 2, dam weight, normal storage level, tail water level and sediment 
pressure(operating condition); case 3, dam weight, design level, tail water level and sediment pressure(operating condition); case 4, dam weight, flood level, tail water level and sediment pressure(operating condition).

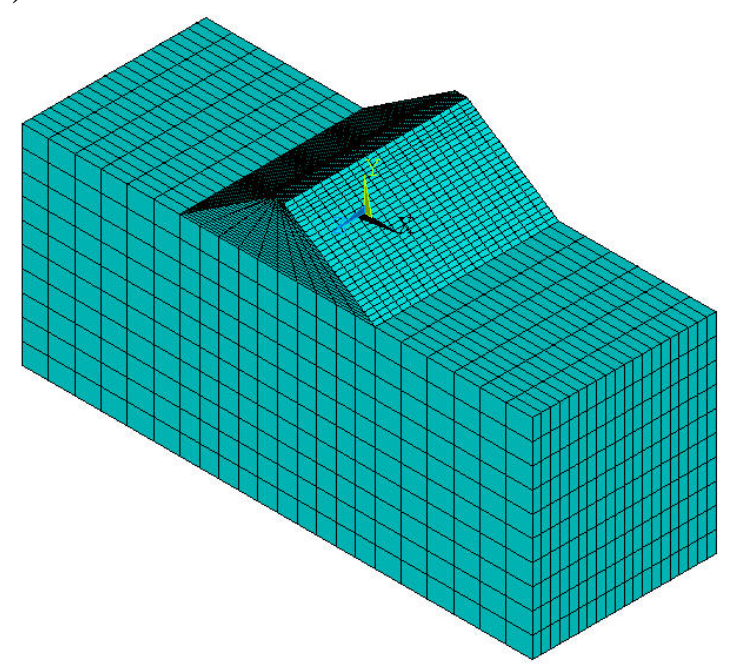

Fig.1 Element division of dam and bedrock

\section{The Dam Structure Analysis}

Analysis Paths. When finite element analysis is proceeded for bitumen residuum concrete core wall rockfill dam of White River hydropower station. two calculation paths are selected in the middle section of the dam. Path 1 , choosing one calculation point every $6.0 \mathrm{~m}$ from dam bottom to dam crest along bitumen residuum concrete core wall rockfill dam's upstream face, there are eight calculation points totally. Path 2, choosing one calculation point every $6.0 \mathrm{~m}$ from dam bottom to dam crest along bitumen residuum concrete core wall rockfill dam's downstream face, there are eight calculation points totally.

Stress Analysis. Calculation point's first principal stress values on the analysis path of bitumen residuum concrete core wall rockfill dam's middle section under various cases are listed in the table 1.

Table 1. Calculation point's first principal stress values on the dam's analysis path under various cases $(\mathrm{kPa})$

\begin{tabular}{|l|c|c|c|c|c|c|c|c|c|}
\hline \multicolumn{2}{|c|}{ Calculation Point } & 1) & (2) & (3) & 4 & 5 & 6 & 7 & (4) \\
\hline \multirow{2}{*}{ Case 1 } & Path 1 & -20.67 & -27.18 & -23.70 & -19.40 & -14.48 & -9.17 & -4.83 & -1.08 \\
\cline { 2 - 10 } & Path 2 & -20.67 & -27.18 & -23.70 & -19.40 & -14.48 & -9.17 & -4.83 & -1.08 \\
\hline \multirow{2}{*}{ Case 2 } & Path 1 & -62.77 & -73.95 & -75.82 & -69.64 & -45.92 & -9.85 & -4.83 & -1.24 \\
\cline { 2 - 10 } & Path 2 & -20.34 & -27.23 & -23.72 & -19.42 & -14.49 & -9.17 & -4.83 & -1.21 \\
\hline \multirow{2}{*}{ Case 3 } & Path 1 & -63.41 & -75.32 & -77.65 & -71.66 & -53.90 & -14.30 & -4.83 & -1.25 \\
\cline { 2 - 10 } & Path 2 & -20.72 & -27.30 & -23.74 & -19.42 & -14.49 & -9.17 & -4.83 & -1.21 \\
\hline \multirow{2}{*}{ Case 4 } & Path 1 & -64.94 & -78.78 & -82.32 & -76.87 & -64.86 & -34.48 & -5.40 & -1.26 \\
\cline { 2 - 9 } & Path 2 & -21.90 & -27.50 & -23.80 & -19.43 & -14.50 & -9.18 & -4.84 & -1.20 \\
\hline
\end{tabular}

We can see from table 1, under various cases, first principal stress on bitumen residuum concrete core wall rockfill dam's calculation paths are compressive stress, but dam's upstream surface's compressive stress values gradually become smaller from dam bottom to dam crest, this is mainly because dam weight and water pressure effect together. Compressive stress values of dam's upstream face and downstream face are increase gradually along with increase of water pressure, this is mainly because the gradients of bitumen residuum concrete core wall rockfill dam's upstream 
face and downstream face are gentle, so the first principal stress that is produced by water pressure is compressive stress on the dam's upstream face and downstream face. Compressive stress values of dam's downstream face are smaller than upstream face, this is mainly because dam's downstream face will produce tensile stress under water pressure, which offsets a part compressive stress.

Because case 3 is common condition of dam in operating process, case 4 is serious condition of dam in operating process. We obtain bitumen residuum concrete core wall rockfill dam's contour maps of first and third principal stress under case 3 and case 4, contour maps of first and third principal stress are shown from Fig.2 to Fig.5.

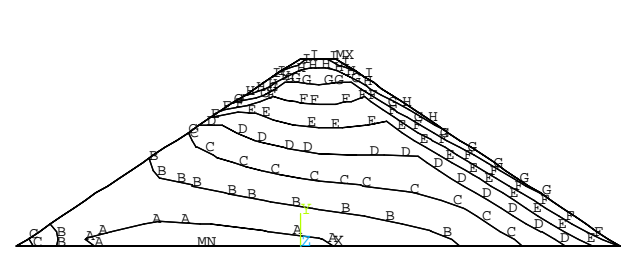

Fig.2 Contour map of first principal stress under case $3(\mathrm{~Pa})$

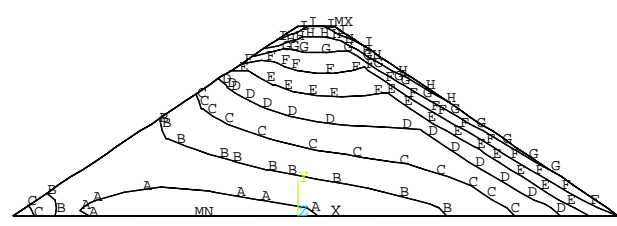

Fig.4 Contour map of first principal

stress under case $4(\mathrm{~Pa})$
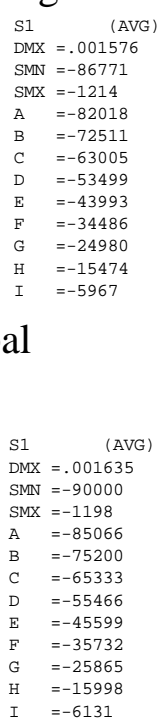

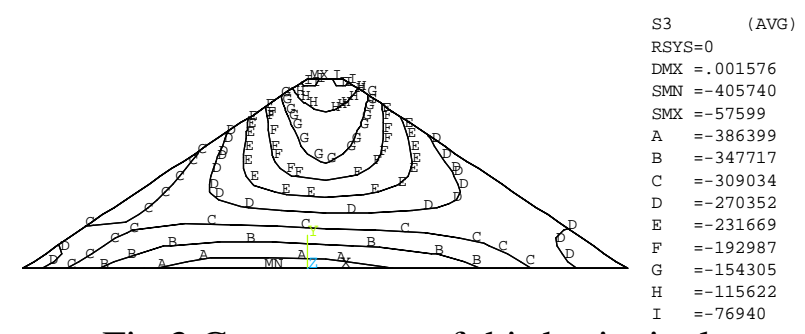

Fig.3 Contour map of third principal stress under case $3(\mathrm{~Pa})$

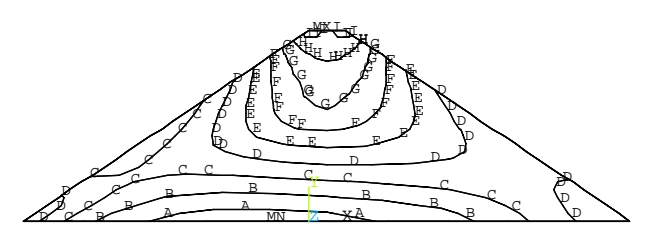

Fig.5 Contour map of third principal stress under case $4(\mathrm{~Pa})$

We can see from Fig.2 to Fig.5, under case 3 and case 4, the dam's first principal stress is entirely compressive stress, and principal stress is layered distribution along the direction of dam height. Stress values the dam's bottom are larger, stress values the dam's crest are smaller, maximum compressive stress is $-0.085 \mathrm{MPa}$, it is located junction of dam bottom and bedrock under case 4 . Under case 3 and case 4, the dam's third principal stress is entirely compressive stress, and principal stress is basically layered distribution along the direction of dam downstream face normal. compressive stress values of downstream face are maximum, compressive stress values decrease gradually from downstream face to upstream face, maximum compressive stress is $-0.397 \mathrm{MPa}$, it is located junction of dam bottom and bedrock under case 4, this is mainly because dam weight and water pressure effect together.

Deformation Analysis. Through deformation analysis of bitumen residuum concrete core wall rockfill dam of White River hydropower station, getting the dam's contour maps of horizontal and vertical displacement in middle section. Contour maps of horizontal and vertical displacement under case 1 and case 4 are shown from Fig.6 to Fig.9.

We can see from Fig.6 to Fig.9, under case 1 and case 4, the dam's horizontal and vertical displacement is smaller, and horizontal displacement value is far less than vertical displacement value, this is mainly because the gradients of bitumen residuum concrete core wall rockfill dam's upstream face and downstream face are gentle, the dam produce mainly vertical settlement displacement under weight and water pressure. Under case 1, axis is bounded, the dam's horizontal displacement value is positive in upstream part, horizontal displacement value is negative in downstream part. The dam's vertical displacement is mainly symmetrical settlement displacement, this is mainly because the dam's weight produces regularity of distribution. Under case 4, the dam's horizontal displacement value is positive, vertical displacement is asymmetric, this is mainly because the dam's weight and water pressure produce regularity of distribution. 


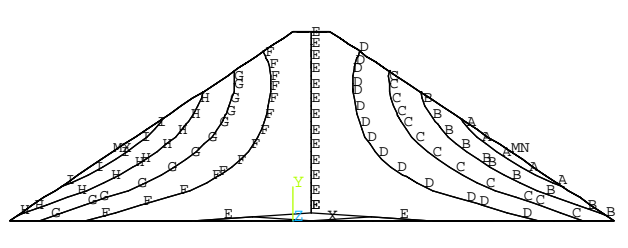

Fig.6 Contour map of horizontal displacement under case $1(\mathrm{~m})$

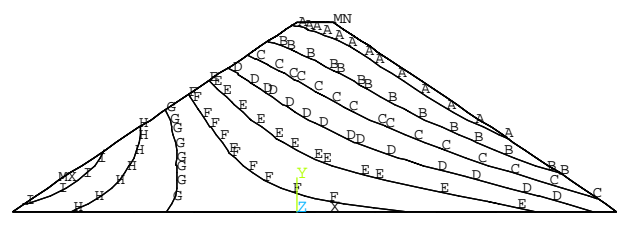

Fig.8 Contour map of horizontal displacement under case $4(\mathrm{~m})$
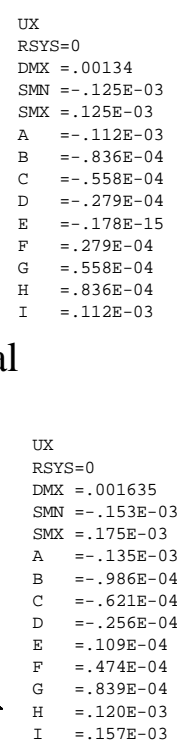

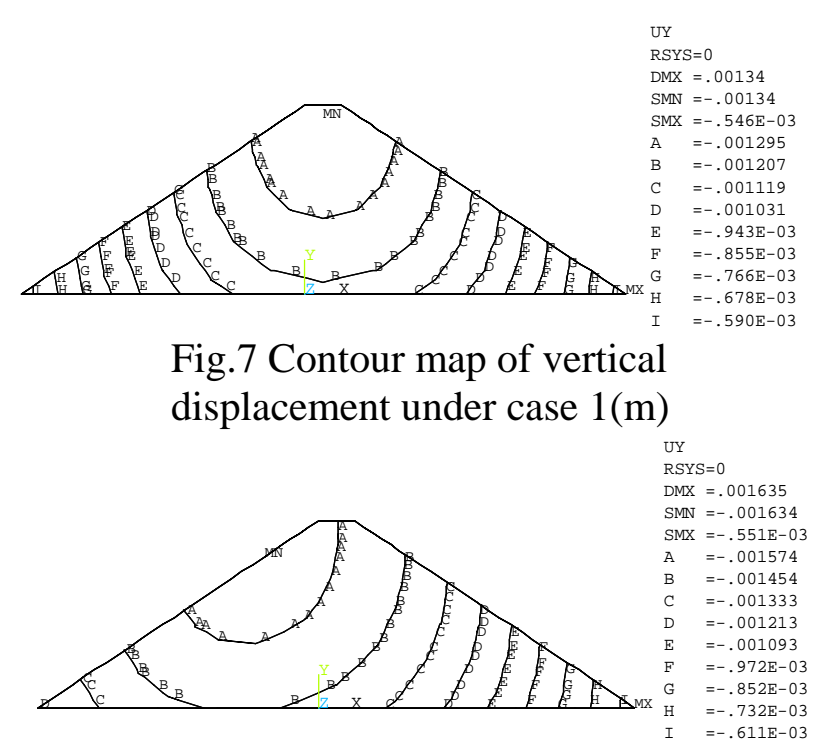

Fig.9 Contour map of vertical displacement under case $4(\mathrm{~m})$

\section{Conclusion}

From the above, in construction process and operational process, bitumen residuum concrete core wall rockfill dam of White River hydropower station's stress is basically compressive stress, the dam won't craze, stress values can meet strength requirements. The dam's displacement value is very small, it can meet rigidity requirements. this shows, design scheme of bitumen residuum concrete core wall rockfill dam is economic and reasonable, structure is safe and reliable.

\section{References}

[1] SL191-2008: Design Code for Hydraulic Concrete Structures(China Water Conservancy and Hydropower Press, China 2008)(in Chinese)

[2] M.R. Shen, J.F. Chen: Rock Mechanics(Tongji University Press, China 2006)(in Chinese)

[3] X.CH. Wang: Finite Element Method(Tsinghua University Press, China 2003)(in Chinese)

[4] K.M. Cao, Y.S. Wang, J.J. Xu, S.H. Liu: Concrete Face Rockfill Dam(China Water Conservancy and Hydropower Press, China 2008)(in Chinese)

[5] X.Q. Luo, X.R. Ge: Concrete Face Rockfill Dam Stress and Strain Analysis Method Research (China Water Conservancy and Hydropower Press, China 2007)(in Chinese) 